\title{
Critical levels of organic acids on seed germination and seedling growth of wheat ${ }^{1}$
}

\author{
Lilian Madruga de Tunes ${ }^{2 *}$, Suemar Alexandre Gonçalves Avelar ${ }^{3}$, Antonio Carlos \\ Souza Albuquerque Barros ${ }^{3}$, Daniele Cardoso Pedroso ${ }^{2}$, Marlove Fátima Brião Muniz², \\ Nilson Lemos de Menezes ${ }^{2}$
}

\begin{abstract}
The objective of this study was to determine the responses of the wheat cultivars CD 108 and CD 111 for tolerance to organic acids. The effects of five concentrations of the three main acids formed in the soil were studied: acetic acid $(0,4,8,12$ and $16 \mathrm{mM})$, propionic acid $(0$, 4, 8, 12 and $16 \mathrm{mM})$ and butyric acid $(0,2,4,8$ and $12 \mathrm{mM})$. Tests included germination, shoot length, root length and dry weight of shoot and root. The variable root length is the most responsive variable for all the acids tested and the critical level of toxicity of acetic, propionic and butyric acids, which reduced root length by at least 50\% was 9.0, 8.5 and $4.0 \mathrm{mM}$ respectively. It was concluded that the presence of acetic, propionic and butyric acids in the germination substratum of wheat seeds of the cultivars CD 111 and CD 108 reduced seedling development, mainly by reducing the length of the radicles.
\end{abstract}

Index terms: Triticum aestivum L., anaerobic decomposition, toxicity, physiological potential.

\section{Níveis críticos dos ácidos orgânicos na germinação e crescimento de plântulas de trigo}

\begin{abstract}
RESUMO - O objetivo deste estudo foi avaliar as respostas das cultivares de trigo CD 108 e CD 111 para tolerância a ácidos orgânicos. Os efeitos de cinco concentrações dos três principais ácidos, formados no solo, foram estudados: ácido acético (0, 4, 8, 12 e $16 \mathrm{mM})$, ácido propiônico $(0,4,8,12$ e $16 \mathrm{mM})$ e ácido butírico $(0,2,4,8$ e $12 \mathrm{mM})$. Os testes realizados foram: germinação, comprimento da parte aérea, comprimento da raiz, massa seca da parte aérea e da raiz. A variável comprimento de raízes é a mais sensível para todos os ácidos e o nível crítico de toxicidade dos ácidos acético, propiônico e butírico, que reduziu em pelo menos $50 \%$ o comprimento da raiz, foi de 9.0, 8.5 e $4.0 \mathrm{mM}$, respectivamente. Concluiu-se que a presença dos ácidos acético, propiônico e butirico em substratos para germinação de sementes de trigo cultivares CD 111 e CD 108 reduz o desenvolvimento de plântulas, principalmente por reduzir o comprimento de raízes.
\end{abstract}

Termos para indexação: Triticum aestivum L., decomposição anaeróbica, toxicidade, potencial fisiológico.

\section{Introduction}

The wheat crop is considered one of the alternatives with most potential for use in crop succession in areas of Southern Brazil dominated by the cultivation of

${ }^{1}$ Submitted on 10/26/2010. Accepted for publication on 01/21/2012.

${ }^{2}$ Departamento de Fitotecnia, UFSM, 97105-900-Santa Maria, RS, Brasil. irrigated rice. In this region there are 6.8 million hectares of agricultural land, consisting of hydromorphic soils, representing $20 \%$ of the total area of Rio Grande do Sul State (Kopp et al., 2007). The development and production of most species cultivated in these soils has been hindered

\footnotetext{
${ }^{3}$ Departamento de Fitotecnia, UFPel, Caixa Postal354,96001-970-Pelotas, RS, Brasil.
}

*Corresponding author<lilianmtunes@yahoo.com.br> 
by the poor natural drainage, resulting in an anaerobic environment, favoring the formation of toxic substances (Camargo et al., 1995).

Also, with the incorporation of crop residues into the soil before the planting of a new crop, there is a potential problem of phytotoxic products originating from the decomposition of incorporated organic material, having negative effects, thereby limiting seedling germination and establishment (Camargo et al., 2001). Therefore, the poor soil drainage in these areas causes anaerobic conditions, which associated with the presence of organic matter, enables the development of anaerobic microorganisms that produce phytotoxic substances, among which stand out the organic acids, such as butyric, acetic and propionic acids.

The toxic effect of these acids depends on their type and concentration (Rao and Mikkelsen, 1977a), with concentrations ranging between 0.1 to $14 \mathrm{mM}$ (Kopp et al., 2010) and usually at a ratio of 6:3:1 of butyric, acetic and propionic acids (Bohnen et al., 2005). These acids reach maximum values a few days after flooding and may cause toxicity to the plants (Sousa and Bortolon, 2006). This toxicity is observed in the early stages of crop development, reducing germination, root growth and seedling weight and height (Kopp et al., 2007).

The scarce literature available highlights the need for more studies with respect to the materials and methods used to evaluate the toxicity of organic acids, since most studies are old and describe a methodology that does not reflect the current experimental conditions used in these types of study. Thus, in order for the cultivation of wheat to become a viable economic alternative in the low lands, cultivars which tolerate the major organic acids produced by the decomposition of organic matter must be used. Therefore, the importance of this study lies in the possibility of recognizing the effects of acids on the physiological quality of wheat seeds.

\section{Material and Methods}

The study was conducted at the Teaching Laboratory of Seed Analysis, Department of Plant Science, Federal University of Santa Maria - Campus Camobi. Seeds of the wheat cultivars CD 111 and CD 108 from COODETEC were used and submitted to the germination test $(\mathrm{G})$, and the shoot length (SL), root length (RL), shoot dry matter (SDM) and root dry weight (RDM) were determined. The effects of five concentrations of the three main organic acids formed in lowland soils were studied: acetic acid $(0$,
4, 8, 12 and $16 \mathrm{mM})$, propionic acid $(0,4,8,12$ and $16 \mathrm{mM})$ and butyric acid $(0,2,4,8$ and $12 \mathrm{mM})$.

Seeds were soaked in acid solutions with the concentrations mentioned above, for a period of 90 minutes. Afterwards the seeds were removed and wrapped in a paper towel for drying to be faster and more uniform. The seeds were then tested for germination $(\mathrm{G})$, shoot length (CPA), root length (RL), shoot dry matter (SDM) and root dry weight (RDM).

The germination test was conducted with four replicates of 100 seeds, sown in rolled paper towel (germitest), moistened with distilled water at a ratio of 2.5 times the weight of dry paper, at $20{ }^{\circ} \mathrm{C}$, with counts made on the eighth day after sowing. The results were expressed as a percentage of normal seedlings (Brasil, 2009).

The average length of 10 , randomly selected normal seedlings, obtained from the sowing of four replicates of 20 seeds in the upper third of the towel paper, was determined. The paper rolls containing the seeds remained for five days in a germinator, at $20^{\circ} \mathrm{C}$. The length of the seedling shoot and root was then determined using a millimeter ruler. The average length of the root, measured from the colon to the apex, was calculated by adding up the measurements of each replicate and dividing by the number of normal seedlings evaluated to obtain the average. The results were expressed in centimeters (Brasil, 2009).

Afterwards, the seedlings were dissected, separating the root system of the shoot, which was placed in aluminum capsules, incubated with convection set at $64{ }^{\circ} \mathrm{C}$ for 72 hours. Subsequently, the dry weight was determined, using a precision scale $(0.0001 \mathrm{mg})$ and the results expressed in g.seedling ${ }^{-1}$.

The concentrations of organic acids were analyzed separately and the results were submitted to an analysis of variance; the germination averages were compared by the Tukey test at the $5 \%$ probability level, and the other variables (length and dry weight of shoot and root) were subjected to a polynomial regression analysis using the statistical analysis program SASM-Agri (Canteri et al., 2001).

\section{Results and Discussion}

The concentrations of organic acids used in this experiment were selected from previous studies, which had concluded that the phytotoxicity of organic acids increases in the order: acetic, propionic and butyric acids, since the longer the acid carbon chain, the more toxic it will be, according to (Takijima, 1964; Rao and Mikkelsen, 1977a and b).

According to the results presented in Table 1, the 
germination percentage of the seeds of the CD 108 and CD 111 cultivars was not reduced by any of the doses of acetic acid tested. However, data from Lynch (1980) showed that acetic acid doses were closely related to the stage of seed germination, such as in barley, which showed a $77 \%$ inhibition of germination for the dose of $12 \mathrm{mM}$.

Table 1. Percentage germination (G\%) of wheat seeds submitted to concentrations of $0 ; 4 ; 8 ; 12$ and $16 \mathrm{mM}$ of acetic and propionic acids and to concentrations of $0 ; 2 ; 4 ; 8$ and $12 \mathrm{mM}$ of butyric acid, in 2008.

\begin{tabular}{|c|c|c|c|c|c|c|c|}
\hline \multicolumn{8}{|c|}{ Acetic acid } \\
\hline \multirow{4}{*}{$\mathrm{G}(\%)$} & \multirow{2}{*}{ Cultivars } & \multicolumn{6}{|c|}{ Concentration } \\
\hline & & $0 \mathrm{mM}$ & $4 \mathrm{mM}$ & $8 \mathrm{mM}$ & $12 \mathrm{mM}$ & $16 \mathrm{mM}$ & CV (\%) \\
\hline & CD 108 & $86 a^{*}$ & $84 a$ & $84 a$ & $82 \mathrm{a}$ & $80 \mathrm{a}$ & 3.45 \\
\hline & CD 111 & $87 \mathrm{a}$ & $85 \mathrm{a}$ & $85 \mathrm{a}$ & $83 a$ & $79 a$ & 2.51 \\
\hline \multicolumn{8}{|c|}{ Propionic acid } \\
\hline \multirow{4}{*}{$\mathrm{G}(\%)$} & \multirow{2}{*}{ Cultivars } & \multicolumn{6}{|c|}{ Concentration } \\
\hline & & $0 \mathrm{mM}$ & $4 \mathrm{mM}$ & $8 \mathrm{mM}$ & $12 \mathrm{mM}$ & $16 \mathrm{mM}$ & CV (\%) \\
\hline & CD 108 & $86 a$ & $86 a$ & $79 \mathrm{~b}$ & $76 \mathrm{~b}$ & $70 \mathrm{c}$ & 5.05 \\
\hline & CD 111 & $87 \mathrm{a}$ & $87 \mathrm{a}$ & $81 \mathrm{~b}$ & $76 \mathrm{c}$ & $68 \mathrm{c}$ & 3.77 \\
\hline \multicolumn{8}{|c|}{ Butyric acid } \\
\hline \multirow{4}{*}{$\mathrm{G}(\%)$} & \multirow{2}{*}{ Cultivars } & \multicolumn{6}{|c|}{ Concentration } \\
\hline & & $0 \mathrm{mM}$ & $2 \mathrm{mM}$ & $4 \mathrm{mM}$ & $8 \mathrm{mM}$ & $12 \mathrm{mM}$ & $\mathrm{CV}(\%)$ \\
\hline & CD 108 & $86 a$ & $85 a$ & $83 a$ & $77 \mathrm{~b}$ & $71 \mathrm{c}$ & 3.61 \\
\hline & CD 111 & $87 a$ & $85 a$ & $85 a$ & $80 \mathrm{~b}$ & $77 \mathrm{~b}$ & 4.69 \\
\hline
\end{tabular}

* Means followed by the same letters in the row do not differ by the Tukey test at $5 \%$ probability.

The root length of wheat seedlings decreased significantly with increasing doses of acetic acid (Figure 1a) up to the highest concentration tested. In the early stages of plant development, root growth was more affected than shoot growth and the degree of toxicity of organic acids is measured by the reduction in root growth. To reduce the root growth of the wheat cultivars tested by $50 \%$, a concentration of approximately $9.0 \mathrm{mM}$ of acetic acid was needed for both cultivars. According to Kopp et al. (2009), an acetic acid concentration of $2.0 \mathrm{mM}$ was needed to reduce the length of the root system of soybeans by $50 \%$, whereas for sorghum, the concentration was $1.8 \mathrm{mM}$. Takijima (1964) demonstrated that a concentration of $5.0 \mathrm{mM}$ acetic acid was damaging to rice, causing a $50 \%$ reduction in root growth and an $18 \%$ reduction in shoot growth.

The lower root growth probably occurred because the acetic acid affects the integrity of the plasma membrane and interferes in energy production processes in the plant, such as oxidative phosphorylation and respiration, as reported by Armstrong and Armstrong (2001). According to Tunes et al. (2008), monocarboxylic acids, such as acetic acid, alter the composition of organic acids in the plasma membrane, promoting a reduction in the proportion of polyunsaturated acids, and affecting important properties of the membrane, such as selectivity.

For the shoot length and dry weight (Figures $1 \mathrm{~b}$ and $1 \mathrm{~d}$ ), a differential response of wheat seedlings was also observed with the same occurring with the root length and dry weight of both cultivars (Figures 1a and 1c). However, the reductions were very similar for both, probably due to the result of the lowest root growth.

For propionic acid, a significant difference was observed for the $8 \mathrm{mM}$ concentration, because there was a decrease in percentage germination (Table 1). These differences were significant, ranging from $79 \%$ to $70 \%$ for the CD 108 cultivar and $81 \%$ to $68 \%$ for the CD 111 cultivar, compared to the highest concentration $(16 \mathrm{mM})$.

Regarding the phytotoxic action of propionic acid, an adjustments of the regression (Figure 2) showed that the average behavior of the variables was similar to that observed with acetic acid. The variable root length (Figure 2a) was the most responsive variable, with a significant reduction at 4 $\mathrm{mM}$. The cultivars showed differential responses only for the root length, with a $50 \%$ reduction when the dose between 8 and $9 \mathrm{mM}$ of this acid was applied. 

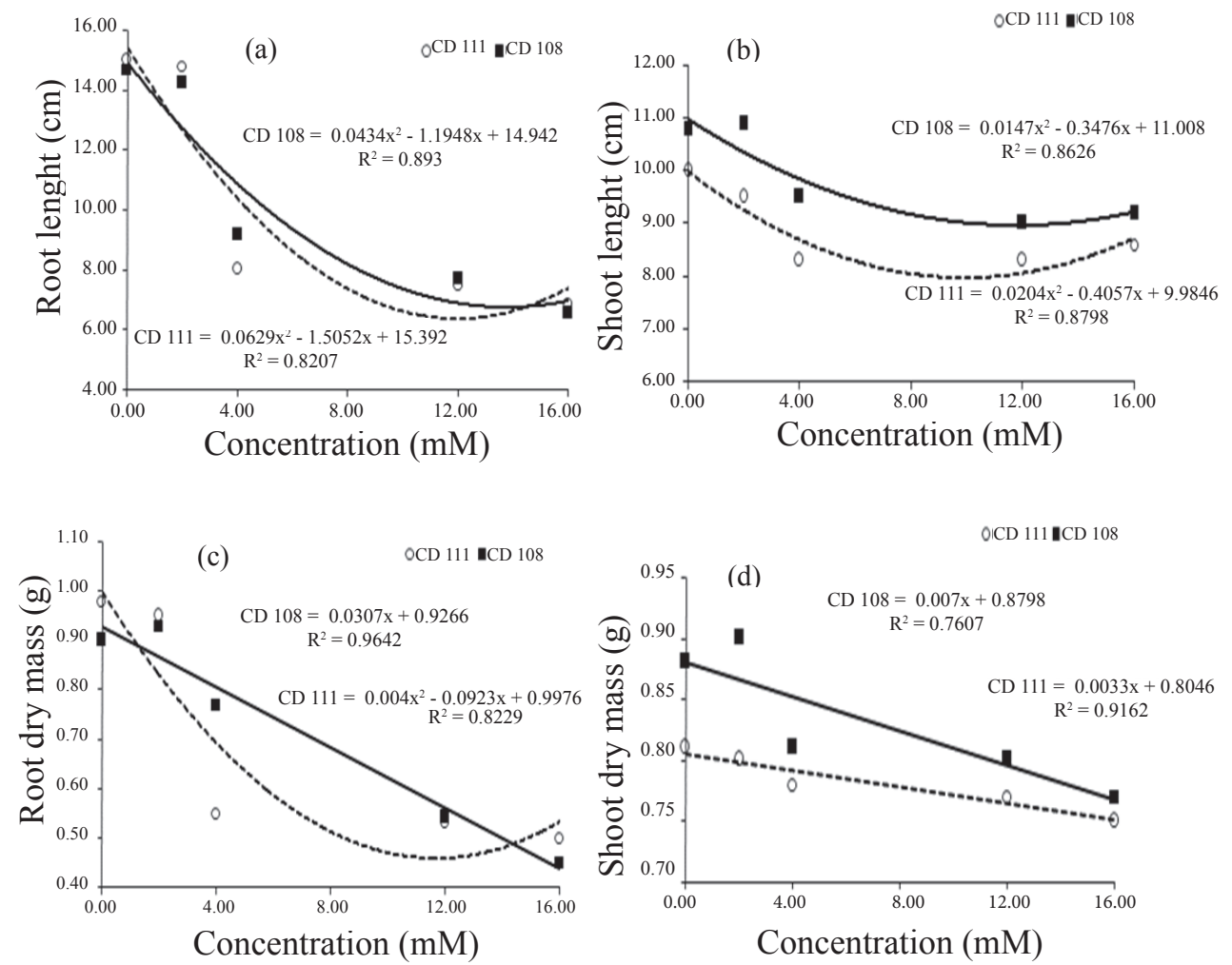

Figure 1. Responses of the variables of root length (RL), shoot length (CPA), root dry weight (RDM) and shoot dry weight (SDM) in relation to four concentrations of acetic acid in cultivars CD 108 and CD 111.
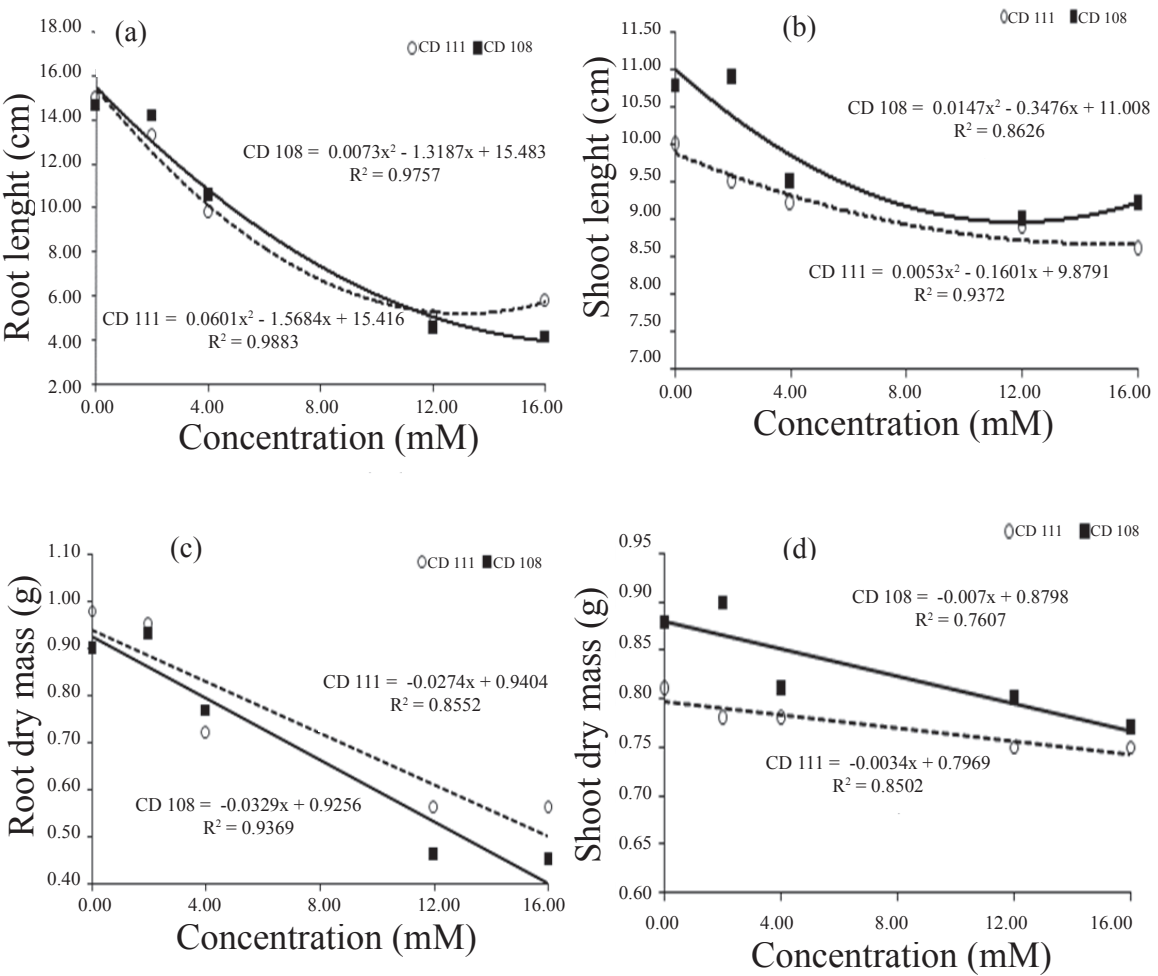

Figure 2. Responses of the variables root length (RL), shoot length (CPA), root dry weight (RDM) and shoot dry weight (SDM) in relation to four concentrations of propionic acid in the cultivars CD 108 and CD 111. 
The root length was the major variable to respond, with an average reduction of up to $73.5 \%$ at the highest dose, followed by dry weight of the aerial part with a relative reduction of $44 \%, 15.2 \%$ for the shoot length, and $6.25 \%$ for the shoot dry weight.

The shoot length showed a lower reduction when compared with the root length (Figure 2b), contradicting the results obtained by Camargo et al. (1993), who observed a similar performance to the root length. This may be due to the seedling having seed nutritional reserves in the early stages, and having greater difficulty to develop roots. Since the root system is the part of the seedling in which the absorption capacity is concentrated, it is the fastest and most extensively part damaged when the water it absorbs has organic acids (toxic substances). The organic acids in contact with the root system are at their peak concentration. When absorbed by the root system the organic acids are distributed throughout the seedling, so that when they come to the shoot, they arrive at a much lower concentration. Thus, the shoot suffers far fewer toxic effects.
With an increasing dose of propionic acid, there was a linear reduction in the dry weight of shoots and, especially, of the roots (Figures $2 \mathrm{c}$ and $2 \mathrm{~d}$ ).

For butyric acid, there was significant difference in concentrations of $8 \mathrm{mM}$ and $12 \mathrm{mM}$, because of a reduction in percentage germination (Table 1). However, these differences were minimal, ranging from $77 \%$ to $71 \%$ of germination for the CD 108 cultivar and $80 \%$ to $77 \%$ for the CD 111 cultivar. Data from Krogmeier and Bremner (1990), testing doses of 8 and $12 \mathrm{mM}$ butyric acid in maize and barley, observed a reduction in germination of $56 \%$ and $35 \%$ respectively.

Figure 3 illustrates the responsiveness of the variables to the phytotoxic action of butyric acid in the CD 108 and CD 111 cultivars. The root length (Figure 3a) also showed the greatest reduction in response to the treatments with an average reduction of approximately $72 \%$ at the highest dose. For a reduction of $50 \%$ of root length, doses of $3 \mathrm{mM}$ of butyric acid for the CD 108 cultivar and $5 \mathrm{mM}$ for the CD 111 cultivar were necessary.
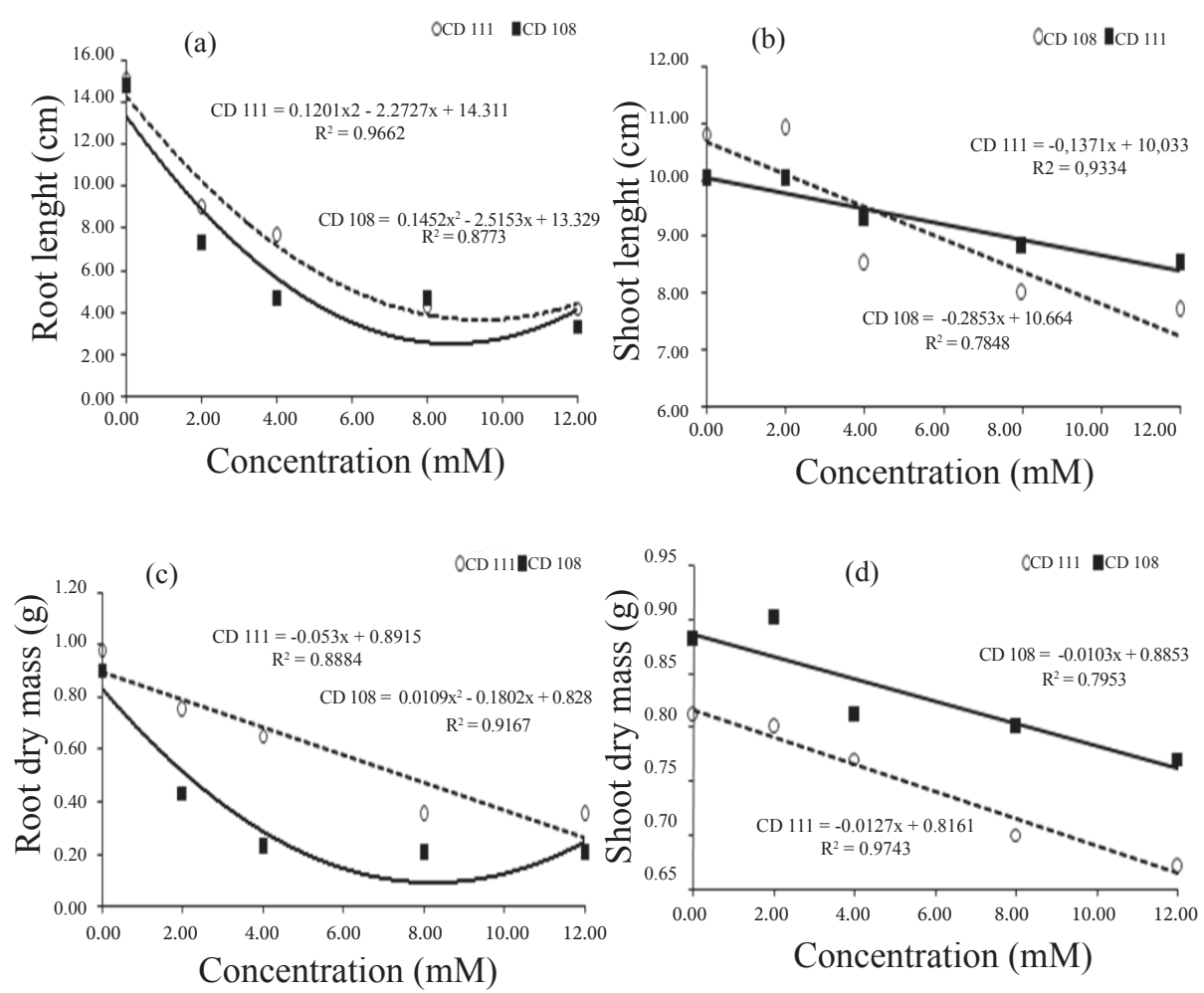

Figure 3. Responses of the variables root length (RL), shoot length (CPA), root dry weight (RDM) and shoot dry weight (SDM) in relation to four concentrations of butyric acid in the cultivars CD 108 and CD 111.

The shoot length and root and shoot dry weights showed a differential response in cultivars facing stress. For the shoot length both cultivars showed a similar response with reduction at the dose of $12 \mathrm{mM}$ between $10 \%-27 \%$ 
(Figure $3 b$ ). The root and shoot dry weights were also reduced with increased concentrations of butyric acid. However, the reduction in shoot dry weight was smaller than for the root dry weight (Figures $3 \mathrm{c}$ and $3 \mathrm{~d}$ ).

The results suggest that acetic acid was less toxic, since to promote a $50 \%$ reduction in root length (the most affected variable) an average concentration of $9.0 \mathrm{mM}$ was necessary. On the other hand, for propionic and butyric acids, concentrations averaging 8.5 and $4.0 \mathrm{mM}$, respectively, were necessary to cause the same effect. Therefore, it may be concluded that butyric acid is the most phytotoxic organic acid, showing a large difference to propionic acid.

According to the data from Tunes et al. (2008), who studied the concentrations of acetic, propionic and butyric acids in the oat cultivars URS 23 and UPF 16, with increasing concentrations of organic acids, there is a reduction in both the length and the weight of dry matter of roots, and it was concluded that these acids affect the physiological quality of oat seeds.

According to Neves et al. (2007), it is necessary to do tests of germination and seedling growth (length of seedling and dry weight) to measure the effects of acetic, propionic and butyric acids on seed vigor. The same authors argue that the presence of more than four tons per hectare of green matter is likely to seriously damage rice germination and other alternative winter crops sown in rice growing areas, such as oats and wheat. The results show that solutions of organic acids in water, with the volume exceeding $12 \mathrm{mM}$, significantly reduce germination. According to Neves et al. (2007), this would correspond to about two to three tons per hectare of green matter in soils under flooding conditions, such as rice.

\section{Conclusions}

The presence of acetic, propionic and butyric acids in the germination substratum of wheat seeds of the CD 111 and CD 108 cultivars reduces the development of seedlings, mainly by reducing the length of the radicles.

\section{References}

ARMSTRONG, J.; ARMSTRONG, W. Rice and Phragmites: effects of organic acids on growth, root permeability, and radial oxygen loss to the rhizosphere. American Journal of Botany, v.88, p.1359-1370, 2001.

BOHNEN, H.; SILVA, L.S.; MACEDO, V.R.M.; MARCOLIN, E. Ácidos orgânicos na solução de um gleissolo sob diferentes sistemas de cultivo com arroz irrigado. Revista Brasileira de Ciência do Solo, v.29, p.475-480, 2005._http://www.scielo.br/pdf/rbcs/v29n3/25748.pdf f
BRASIL. Ministério da Agricultura, Pecuária e Abastecimento. Regras para análise de sementes. Ministério da Agricultura, Pecuária e Abastecimento. Secretaria de Defesa Agropecuária. Brasília, DF: MAPA/ACS, 2009. 395p. http://www.agricultura.gov.br/arq editor/file/ Laborat\%C3\%B3rio/Sementes/Regras $\% 20$ para $\% 20$ Analise $\% 20$ de $\% 20$ Sementes.pdf

CAMARGO, F.A.O; SANTOS, G.A.; ROSSIELlO, R.O.P. Efeito dos ácidos acético e butírico sobre o crescimento de plântulas de arroz. Pesquisa Agropecuária Brasileira, v.28, p.1011-1018, 1993. http:// webnotes.sct.embrapa.br/pdf/pab1993/setembro/pab04_set_93.pdf

CAMARGO, F.A.O.; SANTOS, G.A.; ROSSIELLO, R.O.P.; ZONTA, E. Incorporação de palha de arroz em um gleissolo e efeitos no rendimento da cultura do arroz irrigado. Pesquisa Agropecuária Brasileira, v.30, p.983-987, 1995. http://www.alice.cnptia.embrapa.br/bitstream/ doc/104259/1/pab9513jul.pdf

CAMARGO, F.A.O.; ZONTA, E.; SANTOS, G.A.; ROSSIELO, R.O.P. Aspectos fisiológicos e caracterização de toxidez a ácidos orgânicos voláteis em plantas. Ciência Rural, v.31, p.523-529, 2001. http://www. scielo.br/pdf/cr/v31n3/a29v31n3.pdf

CANTERI, M.G.; ALTHAUS, R.A.; VIRGENS FILHO, J.S.; GIGLIOTI, E.A.; GODOY, C.V. SASM-Agri: sistema para análise e separação de médias em experimentos agrícolas pelos métodos Scott-Knott, Tukey e Duncan. Revista Brasileira de Agrocomputação, v.1, p.18-24, 2001. http:/www.agrocomputacao.deinfo.uepg.br/dezembro_2001/Arquivos/ RBAC_Artigo_03.pdf

KOPP, M.M.; LUZ, V.K.; COIMBRA, J.L.M.; SOUSA, R.O.; CARVALHO, F.I.F.; OLIVEIRA, A.C. Níveis críticos dos ácidos acético, propiônico e butírico para estudos de toxicidade em arroz em solução nutritiva. Acta Botânica Brasílica, v.21, p.147-154, 2007. http://www. scielo.br/pdf/abb/v21n1/14.pdf

KOPP, M.M.; LUZ, V.K.; MAIA, L.C.; SOUSA, R.O.; CARVALHO, F.I.F.; OLIVEIRA, A.C. Avaliação de genótipos de aveia branca sob estresse de ácidos orgânicos. Bragantia, v.68, n.2, p.329-338, 2009. http://www.scielo. br/scielo.php?script=sci_arttext\&pid=S0006-87052009000200006

KOPP, M.M.; LUZ, V.K.; MAIA, L.C.; COIMBRA, J.L.M.; SOUSA, R.O.; CARVALHO, F.I.F.; OLIVEIRA, A.C. Avaliação de genótipos de arroz sob efeito do ácido butírico. Acta Botanica Brasilica, v. 24, n.2, p. 578-584, 2010. http://www.scielo.br/pdf/abb/v24n2/a27v24n2.pdf

KROGMEIER, M.J.; BREMNER, J.M. Effects of aliphatic acids on seed germination and seedling growth in soil. Communications in Soil Science and Plant Analysis, v.21, p.547-555, 1990.

LYNCH, J M. Effects of organic acids on the germination of seeds and growth seedling. Plant, Cell and Environment, v.3, p.255-259, 1980.

NEVES, L.A.S.; MORAES, D.M.; LOPES, N.F.; ABREU, C.M. Vigor de sementes e atividade bioquímica em plantas de arroz submetidas a ácidos orgânicos. Pesquisa Agropecuária Gaúcha, v.1-2, p.79-80, 2007. http://www. fepagro.rs.gov.br/upload/20120223173954vol_13_n_1_e_2__art_10.pdf 
RAO, D.N.; MIKKELSEN, D.S. Effect of acetic, propionic, and butyric acids on young rice seedlings growth. Agronomy Journal, v.69, p.923-928, 1977a.

RAO, D.N.; MIKKELSEN, D.S. Effect of acetic, propionic, and butyric acids on rice seedlings growth. and nutrition. Plant and Soil, v.47, p.323-334, 1977 b.

SOUSA, R.O.; BORTOLON, L. Crescimento radicular e da parte aérea do arroz (Oryza sativa L.) e absorção de nutrientes em solução nutritiva com diferentes concentrações de ácido acético. Revista Brasileira de Agrociência, v.8, p.231-235, 2006. http://www.ufpel.tche.br/faem/ agrociencia/v8n3/artigo 10.pdf
TAKIJIMA, Y. Growth inhibiting action of organic acids and absorption and decomposition of them by soils. Soil Science Plant Nutrition, v.12, p.435-442, 1964.

TUNES, L.M.; OLIVO, F.; BADINELLI, P.G.; CANTOS, A.; BARROS, A.C.S.A. Aspectos fisiológicos da toxidez de ácidos orgânicos em sementes de aveia. Biotemas, v.21, p.21-28, 2008. http://www.biotemas. ufsc.br/volumes/pdf/volume214/p21a28.pdf 